\title{
Diacronie
}

Studi di Storia Contemporanea

$N^{\circ} 25,1 \mid 2016$

"Se creare è definire"

\section{Contemporary History in High Schools}

Brazilian, North American and French Content Standards (1999-2014)

\section{Itamar Freitas}

\section{(2) OpenEdition \\ Journals}

Electronic version

URL: http://journals.openedition.org/diacronie/3985

DOI: 10.4000/diacronie.3985

ISSN: 2038-0925

Publisher

Association culturelle Diacronie

\section{Electronic reference}

Itamar Freitas, "Contemporary History in High Schools », Diacronie [Online], № 25, 1 | 2016, document 9, Online since 29 March 2016, connection on 24 April 2019. URL : http://journals.openedition.org/ diacronie/3985; DOI : 10.4000/diacronie.3985 


\title{
Diacronie
}

9/

\section{Contemporary History in High Schools ${ }^{1}$ :}

\section{Brazilian, North American and French Content \\ Standards (1999-2014)}

\author{
Itamar FREITAS *
}

This article discusses Contemporary History $(\mathrm{CH})$ during the formation of students in high school years. The objects are the assigned curricula for high schools in Brazil, USA and France in the last two decades. By using comparative History strategies, we examine how present time is configured in different cultures, the ways in which the State appropriates itself of this period's historical representation in school programs and standards, the historians' degree of intervention (and that of $\mathrm{CH}$ in particular) in the elaboration of curricula for the teaching of History and the representations these countries make of each other on the theme of the $20^{\text {th }}$ and $21^{\text {st }}$ centuries.

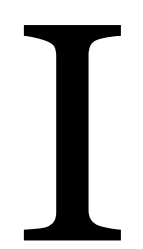

$\mathrm{n}$ this article $^{1}$ we examine the different meanings attributed to, justified, explained and assigned for the present time as contentinthe school subject of History in different cultures. At the same time werecall - and whenever necessary we elaborate on - the discussions that usually take place in the undergraduate and graduate courses for future History teachers in the University of Brasília $^{2}$. We mainly refer to the public uses of history, to the distinctions between past

\footnotetext{
${ }^{1}$ Summary of the post-doctoral report, completed at the Graduate Program in History at the University of Brasília, under the supervision of PhD Arthur Assis Alfaix, between December 2014 and November 2015 with CAPES (Coordination for the Improvement of Higher Education Personnel) funds.

${ }^{2}$ We refer to the project developed in the 2013-2015 period, that lends this article its title, involving the analysis of the relationship between $\mathrm{CH}$ and academic historiography, $\mathrm{CH}$ and undergraduate courses for History teachers' curriculum and between $\mathrm{CH}$ and curricula assigned for secondary schools. We will debate only the last one in this article.
} 
and present made by different historiographies ${ }^{3}$ and to the relationshipin a transnational perspectivetbetween politics and history, State and historical knowledge production 5 .

We explore Contemporary History $(\mathrm{CH})$ here especially in its extra-academic experience. That is, we analyze public policies for the area, such as in the producing of parameters, curriculum frameworks and nationalstandards, large-scale evaluations and teaching programs that have given birth to the famous «cultural wars for the teaching of History» ${ }^{6}$, across different countries along the last two decades, disclosing left and right wing, conservative and progressive positions.

The chosen countriesare Brazil, regarded as an emerging economy for the $21^{\text {st }}$ century, the United States of America (USA), world's superpower in the $20^{\text {th }}$ century, and France, one of the leaders of the $19^{\text {th }}$ century. This is, therefore, a work of comparative history that benefits from all the advantages of this type of approach: the identification of problems, explanation of singularities, critics to a stereotyped perception of the same problems in one or other country and the revision or confirmation of generalizations over educational issues7.

Besides the overtly declared political interest and the comparative approach, the choice for these countries was due to the different ways in which their citizens' right to the past is managed8: the North-American State leaves each member of the federation in charge of the task to prescribe its own curricula; the French one centralizes the production of learning expectations; the Brazilian leaves its federate members free to produce curricula in spite of actually controlling their contents by determining national exams and by regulations attached to the budget distribution. These conditionals entail

\footnotetext{
${ }^{3}$ BEVERNAGE, Berber, LORENZ, Chriz, «Breaking up Time. Negotiating the Borders between Present, Past and Future», in Storia della Storiografia, 63, 1/2013, pp. 31-51.

4 MARTINS, Estevão de Rezende, «Conhecimento histórico e historiografia brasileira contemporânea», in Revista Portuguesa de História, 42, 2011, pp. 197-210.

${ }^{5}$ ID., «História e teoria na era dos extremos», in Fenix. Revista de História e Estudos Culturais, 3, 2/2006, pp. 1-19. At this point, we may have made it clear that we understand the teaching of History as a Theory of History and History of Historiography object.

${ }^{6}$ TAYLOR, Tony, GUYVER, Robert, «A Review Essay on the History Wars: Ten Case Studies in Controversy», in International Journal of History Teaching, Learning and Research, 10, 2/2012, pp. 68-72.

${ }^{7}$ HAUPT, Heinz-Gerhard, KOCKA, Jürgen, Comparison and Beyond: Traditions, Scope, and Perspectives of Comparative History, in ID. (edd.), Comparative and Transnational History: Central European Approaches and New Perspectives,New York, Berghahn Books, 2009, pp. 1382.

${ }^{8}$ OLIVEIRA, Margarida Maria Dias de, O direito ao passado: uma discussão necessária à formação do profissional de história, São Cristóvão, Editora UFS, 2011.
} 
an asymmetrical comparison that tries to understand certain particularities in a case while observing others of a different nature9.

Based on these references, conditionals and motivations, we mean to answer the following questions: how do different cultures configure the present? How are different historical representations appropriated by the State in terms of curricula and school programs? To what degree do historians (and $\mathrm{CH}$ historiography in particular) interfere in the production of contents for the teaching of History? What representation does each country make of the other when it comes to the experiences of the $20^{\text {th }}$ and $21^{\text {st }}$ centuries?

These questions are obviously related to our own political interests. Brazil shallgo through intense debates during the 2015-2016 period due to the discussion of the National Curriculum Standards for basic education ( $1^{\text {st }}$ to $13^{\text {th }}$ grade - elementary, middle and high schoolio) and the subsequent reformulation of our correspondent undergraduate courses for future teachers. Thus, we believe that the comparative analysis of other curricula assignments may contribute to the reflection and to the decisions that will guide the forming of people for teaching in the next few years. The four following topics explore our methodological choices and, most importantly, the $\mathrm{CH}$ ideas grasped from the highschool levels in Brazil, France and USA.

\section{A Little Bit of CH}

$\mathrm{CH}$ and its correspondents in different cultures - Temps Présent [Present Time] and Histoire Proche [Recent History] in France, Contemporary History in England, Contemporary History and History of Our Own Time in the USA, Zeitgeschichte [Contemporary History], Neueste Geschichte [Recent History] and Nueste Zeitgescichte [New Contemporary History] in Germany ${ }^{11}$ - are related to the different individual and institutional experiences, inside and outside the historians' fields of work, that emerge at the same time in countries such as Germany, England, France and Spain ${ }^{12}$.

\footnotetext{
${ }^{9}$ HAUPT, Heinz-Gerhard, KOCKA, Jürgen, op. cit.

${ }^{10}$ We are considering the North American division for school levels (TN).

${ }^{11}$ For an analysis on terminologies differences, refer to ARÓSTEGUI, Julio, La historia vivida: sobre la historia del presente, Madrid, Alianza, 2004, pp. 28-31 and ROUSSO, Henry, «The Last Catastrophe. The Writing of Contemporary History», in Cadernos do Tempo Presente, 11, 1/2013, URL: < http://www.getempo.org/index.php/revistas/56-n-11-marco-de2013/artigos/169-1-the-last-catastrophe-the-writing-of-contemporary-history $>$ [access on February $\left.22^{\text {nd }}, 2016\right]$.

${ }_{12}$ ROUSSO, Henry, «The Last Catastrophe», cit.; PALMOWSKI, Jan, SPOHR READMAN, Kristina, "Speaking Truth to Power: Contemporary History in the Twenty-first Century», in Journal of Contemporary History, 46, 3/2011, pp. 485-505; BERNECKER, Walther, "La
} 
They arise in an attempt to find answers for the "astonishing changes in the societies that survived the catastrophes of the $20^{\text {th }}$ century» ${ }^{13}$, either emphasizing the experience related to the construction/reconstruction of States and national democracies - like in the studies that explore the causes and consequences of dictatorial regimes in Chile, Argentina, Uruguay, Paraguay and Brazil14 - either in the issues that overcome these same nations simultaneously such as terrorism and environmental degradation ${ }^{15}$. They come up as practices devoted to the examination of the nature and repercussions of World War II (1939-1945) and end up reaching out to these big issues witnessed by its own professionals in their societies of origin.

That's how it happened in Germany, after the rising of National Socialism and the extermination of Jews; in Spain after Civil War and the Franco years; in France after the Resistance, the Vichy regime and the colonial defeats ${ }^{16}$. At last, $\mathrm{CH}$ is also born inside the historians' field as a symptom of the paradigmatic crisis related to the historical objectivity ${ }^{17}$.

If we focus on only three of the main historians in the countries we analyze here, USA, Brazil and France, we realize that they approach actions (and their respective emotions) that arise or resurfaceduring their own lifespan: social exclusion in Tony Judt, authoritarianism in Francisco Carlos Teixeira da Silva and different resentments in Henry Rousso ${ }^{18}$. Except for Judt, who will not explicit it (even though the title Ill Fares the Land: a Treatise on Our Present Discontentsmay suggest it), they are all involved with the idea of trauma, set forth by a catastrophe during the $20^{\text {th }}$ century. And not without reason. It is comprehensible why $\mathrm{CH}$ has only sprung up in the second half of the $20^{\text {th }}$ century. No other time period has concentrated so many tragedies that threatened the notion of a continuous mankind improvement. Never before had men come so close to self-destruction ${ }^{19}$ and in no other time have historians oscillated so

investigación histórica del "tiempo presente" en Alemania", in Cuadernos de Historia Contemporánea, 20, 1998, pp. 83-98.

${ }^{13}$ ARÓSTEGUI, Julio, op . cit., p. 27, free translation of the author.

${ }^{14}$ CAPDEVILA, Luc, «La sombra de las víctimas oscurece el busto de los héroes: historia del tiempo presente y construcción democrática (América Latina/Europa)», in Diálogos, 14, 1/2010, pp. 111-119.

${ }^{15}$ PALMOWSKI, Jan, SPOHR READMAN, Kristina, op. cit.

${ }^{16}$ ARÓSTEGUI, Julio, op. cit., pp. 25, 37-44.

${ }^{17}$ IGGERS, Georg G., Historiography in the Twentieth Century: from Scientific Objectivity to the Postmodern Challenge, London, WesleyanUniversity Press, 1997.

${ }^{18}$ JUDT, Tony, O mal ronda a terra: um tratado sobre as insatisfações do presente, São Paulo, Objetiva, 2010; SILVA, Francisco Carlos Teixeira, Vox, voces: (re)memorar,Rio de Janeiro, Multifoco, 2012; ROUSSO, Henry, La dernière catastrophe: l'histoire, le présent, le contemporain, Paris, Gallimard, 2012.

${ }^{19}$ SCHLESINGER JÚNIOR, Arthur, "On the Writing of Contemporary History», in The Atlantic, 3/1967, URL: < http://www.theatlantic.com/magazine/archive/1967/o3/on-the- 
much «between unlimited trust in evidence [...] and a mocking skepticismas to the point of stating the hopeless failure of modern reason $»^{20}$.

These assumptions make us focus on the substantive concepts ${ }^{21}$ concerning the $20^{\text {th }}$ and the beginning of the $21^{\text {st }}$ century in the History curricula for high schoolsin these three countries. In other words, $20^{\text {th }}$ and $21^{\text {st }}$ centuries are the basic historical concepts we will analyze in the curricula ${ }^{22}$. They're a temporality model, even if nonexistent in pure form ${ }^{23}$ in any of the experiences under scrutiny.

Besides the $20^{\text {th }}$ and $21^{\text {st }}$ century, we are also interested in those experiences that are registered as "contemporary", "present day", "today", "recent time" and "until now", considered as historical particulars ${ }^{24}$. It is these "present times" that we discuss ahead, both in the Brazilian, French and North American contents of Contemporary History.

\section{CH in the Programs for Brazilian High Schools25 (1999-2013)}

Let us begin the interrogation on the Brazilian experience by asking: who determines the contents for high school education in Brazil? To what degree do the national documents intervene in the school environment? What is the nature of the "present" suggested by the curricula in each State? What kind of correspondence can we make between the present determined by the State proposals and the Political Pedagogical Projects in the teachers' courses? What representations do the Brazilian programs offer the high school students of present France and USA?

In the first place, it is important to know that there are no unified national standards in Brazil, in spite of the complaints coming from school teachers and

writing-of-contemporary-history/305731/ > [access on March 2nd, 2014]; ROUSSO, Henry, La dernière catastrophe, cit.

${ }^{20}$ MARTINS, Estevão de Rezende, «História e teoria na era dos extremos», cit., p. 2.

${ }^{21}$ By substantive concepts we refer to contents regarding procedure and historical particulars.

${ }^{22}$ RÜSEN, Jörn, Conceitos históricos, in ID., Reconstrução do passado. Teoria da história II: os princípios da pesquisa histórica, Brasília, Editora UnB, 2007, pp. 92-94. They are «linguistic resources that apply a historical interpretation perspective to concrete facts and express its temporal specificity. They are historical because they deal with the relationship between remembering the past and the expectation of the future, and not only because they refer to the past» (free translation). See also ID., Razão histórica. Teoria da história: os fundamentos da ciência histórica, Brasília, EditoraUnB, 2001.

${ }^{23}$ WEBER, Max, $O$ espírito do capitalismo, in ID., A ética protestante e o espírito do capitalismo, 2ed., São Paulo, Pioneira, 2003, pp. 25-41.

${ }^{24}$ RÜSEN, Jörn, Conceitos históricos, cit.,p. 93: they «differ from historical concepts because they come from the evidence and, most of the times, refer to the singular occurrence of the past state of events» (free translation).

${ }^{25}$ Basic education lasts 12 years in Brazil: 5 in elementary school, 4 in middle school and 3in high school (considering the North American equivalent). The age group corresponds to high school in USA and upper secondary education in Europe (Lycée in France). 
especially from the researchers in the teaching of History. That keeps us from commenting on a single national standards document for History in high school level.

It is obvious that the Ministry of Education (MEC) producesstandards and programs, but these documents arenot always coherent between themselves. Besides, the appropriation of these documents in different spaces and time in the Brazilian school experience is quite unknown.

These singularities and deficiencies explain the absence of $\mathrm{CH}$ in the National Curriculum Parameters for the teaching of History (PCN), produced in 1999-2000, for instance, and a $44 \%$ presence in subject areas along the complementary documents for $\mathrm{PCN}(\mathrm{PCN}+)^{26}$. We believe that is the same reason why the African, Afro-Brazilian and Native experience are rarely or indirectly treated ${ }^{27}$. The same may be attested on the surprisingly 50\% to 70\% presence of these objects in the National High School Exam (ENEM), elaborated in 2009, and thatis progressively designing the History curricula for this level of education in all the country ${ }^{28}$.

We also observe a meaningful difference compared to the results obtained from the Political Pedagogical Projects for the History teachers'undergraduate courses. These

\footnotetext{
${ }^{26}$ MINISTÉRIO DA EDUCAÇÃO DO BRASIL, Parecer CNE n. 15/98, de 1 jun. 1998, que institui as Diretrizes Curriculares Nacionais para o Ensino Médio, Brasília, Conselho Nacional de Educação/Câmara de Educação Básica, 1998, accompanies theResolução CNE/CEB n. 3, de 26 de junho de 1998, que institui as Diretrizes Curriculares Nacionais para o Ensino Médio, URL: < http://portal.mec.gov.br/cne/arquivos/pdf/rcebo3_98.pdf > [access on May $7^{\text {th }}$, 2014]; ID., Parâmetros Curriculares Nacionais- Ensino Médio, Brasília, Secretaria de Educação Básica/Ministério da Educação, 2000; ID., Orientações e Ações para a Implementação das Relações Étnico Raciais, Brasília, Secretaria da Educação Continuada, Alfabetização e Diversidade, 2006; ID.,Resolução n. 2, de 30 de janeiro de 2012, que define Diretrizes Curriculares Nacionais para o Ensino Médio, Brasília, Conselho Nacional de Educação/Câmara de Educação Básica, 2012; ID., Resolução n. 8, de 20 de novembro de 2012, define Diretrizes Curriculares Nacionais para a Educação Quilombola na Educação Básica, Brasília, Conselho Nacional de Educação/Câmara de Educação Básica, 2012.

${ }^{27}$ SECRETARIA DA IGULADADE RACIAL DO BRASIL, Plano Nacional de Implementação da Lei n. 10.639/2003, Brasília, Secretaria de Políticas de Promoção da Igualdade Racial, 2004,URL: <http://www.seppir.gov.br/publicacoes/africaescolas.pdf> [access on May $7^{\text {th }}$, 2014]; MINISTÉRIO DA EDUCAÇÃO DO BRASIL, Parâmetros Curriculares Nacionais (Ciências Humanas e suas Tecnologias) - Ensino Médio: orientações educacionais complementares aos Parâmetros Curriculares Nacionais do Ensino Médio, Brasília, Ministério da Educação, 2002, URL: < http://portal.mec.gov.br/seb/arquivos/pdf/CienciasHumanas.pdf> [accesson May $\left.5^{\text {th }}, 2014\right]$; ID., Resolução 1/2004, que institui Diretrizes Curriculares Nacionais para a Educação das Relações Étnico-Raciais e para o Ensino de História e Cultura AfroBrasileira e Africana, Diário Oficial da União, Brasília, Conselho Nacional De Educação, 2004, section 1, p. 11; ID., Orientações Curriculares para o Ensino Médio (Ciências Humanas e suas Tecnologias), Brasília, Secretaria de Educação Básica, 2006; ID., Resolução n. 2, de 30 de janeiro de 2012, cit. ID., Resolução n. 8, de 20 de novembro de 2012,cit.

${ }^{28}$ ID., Edital n. 12, de 8 de maio de 2014 (Exame Nacional do Ensino Médio - ENEM/2014 e Matriz de Referências), Brasília, Instituto Nacional de Estudos e Pesquisas Educacionais Anísio Teixeira, 2014.
} 
spare $39 \%$ of theirhour load to subjects that we consider «contents to teach» ${ }^{29}$ and $25 \%$ of the total hour load for undergraduate courses for the $20^{\text {th }}$ and $21^{\text {st }}$ century. That is, even when national documents give room to $\mathrm{CH}$, they do it much more than the academic environment. $\mathrm{CH}$ is more frequent in the subjects of Brazil History (11\% of the hour load) and Modern History (7,3\%). It is scarcely present in the subjects of History of America (3,7\%) and Local/Regional History (2,5\%) and residual in those related to African, Asian, Afro-Asian and Iberian History: they won't give it even $1 \%$ of their respective hour loads.

As to the State proposals, we notice that the $20^{\text {th }}$ and $21^{\text {st }}$ centuries are dominant in 6 out of the 21 programs $^{30}$, and that they compete in equal terms with the $15^{\text {th }}$ and $16^{\text {th }}$ century's period in another two. For the first group $(\mathrm{CH})$, the number of learning expectations represents an average of $32 \%$. For the second it reaches $30 \%$.

The previous analysis also allows us to state that $\mathrm{CH}$ is mostly transnational (42\% of the expectations listed), when compared to the national (28\%) and local (9\%) experience. Present time in a perspective that intersects transnational, national and local experience reaches only $16 \%$ of the expectations.

There are 15 recurring themes on the substantive nature of this present (present on $50 \%$ or more of the curricula): dictatorship, globalization-mundialization, Cold War, World War II, social movements, Russian and Chinese Revolution, citizenship, Vargas Government, neoliberalism, redemocratization, Crash of 1929, Fascism, Nazism, First Republic and totalitarianism.

This tells us that the universities and the City and State education offices agenda differ as to the amount of space given to $\mathrm{CH}$ but coincide to a certain extent as to $\mathrm{CH}$ substantive concepts, like in the contents named First Republic, authoritarianism/totalitarianism/dictatorship, World War II, Cold War, globalization/mundialization, social movements.

As to the themes that draw the $\mathrm{CH}$ historians' attention, the so-called "newcomers in contemporary historiography", present in specialized vehicles ${ }^{31}$, - environmental, gender, ethnic, fundamentalism, political, epistemological, affective and cognitive

\footnotetext{
${ }^{29}$ GUIBERT, Pascal, TROGER, Vicent, Peut-on encore former des enseignants?, Paris, Armand Colin, 2012.

${ }^{30}$ Brazil has 26 States, but we have had access to the curricula of only 21 of them.

${ }^{31}$ «Cadernos do Tempo Presente»(2010-2014), edited by the Grupo de História do Tempo Presente (GET), of the Federal University of Sergipe (UFS), «Revista Agora» (2007-2014), with no declared institutional filiation, «Revista Tempo e Argumento» (2009-2014), belonging to the Graduate Program in History (PPHG) of the State University of Santa Catarina (UDESC), and «Tempo Presente»(2006-2014), first in the area (entitled as «Boletim do Tempo Presente»), edited by the Laboratório Tempo, of the Graduate Program in Comparative History (PPGHC) of the Federal University of Rio de Janeiro (UFRJ).
} 
issues, raised by the invention of the internet - these are far away from the State proposals.

One other proximity between the proposals and the Political Pedagogical Projects is the geographical range of the substantive contents. In both of them, the local, or rather, the relationship between the local, national and transnational is scant. Latin America, Europe, Africa, Asia, USA, Germany and Soviet Union are the same privileged elements. And at this point we can already reveal the answer to the last question we posed in the beginning of this article: in the State proposals as well, USA are the bad guys of the transnational experience, just as much in the Latin American and national one. France is simply ignored and Brazil is a passive subject in the transnational experience.

We have pointed out the relative symmetry (space and events) between the universities Political Pedagogical Projects and the State standards. However, it is to be determined whether this confluence of priorities is due to what is prescribed and taught in the undergraduate History courses or to the contents systematically exposed in the textbooks that are evaluated and distributed to high schools by the State $3^{2}-$ but that is food for thought. Let us move on to how the same issues are dealt with in the French case.

\section{CH in the French LycéeCurricula (2010-2014)}

The French education system considers the production of curricula as a responsibility of the State, consulting the community of school teachers, inspectors, university professors and union members. The State has the duty to produce, apply, evaluate and revise the programs, while taking heed of different sectors of the society. This operation guarantees the distribution of equal opportunities and also the building of a common cultural formation (with national and universal elements).

Many options are given as regards substantive concepts in the attempt of conciliating the principles of equality (between the students) and freedom (amongst teachers and editors). Such principles are actually confirmed in the last legislation on the subject: the Charte des Programmes ${ }^{33}$. The State intentions are explicit in it:

\footnotetext{
${ }^{32}$ By the ProgramaNacional do LivroDidático, which, translated, should correspond to Textbook National Program.

${ }^{33}$ MINISTERE DE L'ÉDUCATION NATIONALE, DE L'ENSEIGNEMENT SUPERIEUR ET DE LA RECHERCHE DE FRANCE, Charte des Programmes, Paris, Conseil Supérieur des Programmes, 2013.
} 
divulging scientific truths, esthetic, ethical and political principles (equality, freedom, democracy).

The programs are made having in mind the teachers' usage and especially that of the students 34 . Its information outline comprises themes, questions and sentences that detail these same questions and that are chronologically ordered (themes, questions and sentences) suggesting movements towards different directions: world-EuropeFrance or in the reverse order, for example. The sentence distribution also indicates a progression in the order of interest: France $\left(1^{\text {st }}\right)$, world $\left(2^{\text {nd }}\right)$ and Europe $\left(3^{\text {rd }}\right)$.

Although there are different structuresfor high school level in France, History is present in every grade and year, either in the general formation, either in the technological one ${ }^{35}$. The hour load allotted for $\mathrm{CH}$, in turn, differs, being larger in the general courses.

Notwithstanding the differences between the distributions in the hour loads, two characteristics are common to both modalities. Everyone studies Ancient, Middle, Modern and Contemporary History on the first year. On the second one, all themes are concentrated on subjects related to $\mathrm{CH}$.

Concerning the nature of the substantive concepts, we have observed that conjunctures prevail over brief events when it comes to talking about the world,while the contrary happens when it isEurope or France the main subject. A well knowncommonsense knowledge predominates when focusing on the world. On the other hand, when approaching the national experience, we see a mixture of the founding elements of the French nation, concentrated on the Republican experience and taboo issues such as the memory of the collaborationism with the Nazis and the colonial war in Algeria.

34 ID., Enseigner au colège. Histoire-Géograhie, éducation Civique. Programes et accompagnement, Paris, Centre National de Documentation Pédagogique, 2004; ID., «Programes du collège. Programmes de l'enseignement d'histoire-géograhie-éducation civique», in Bulletin Oficiel Spécial, 6, August 28 ${ }^{\text {th }}$, 2008; ID., Direction Générale de l'Enseignement Scolaire. Histoire, Géographie, Éducation civique: classes de sixième, cinquième, quatrième, troisième, Paris, Centre national de documentation pédagogique, 2009; ID., «Les nouveaux programmes du collège et de l'école traduisent une meilleure intégration et un très net renforcement de l'éducation à la défense», June $2^{\text {nd }}, 2008$ (updated in August 2011), URL:

$<\quad$ http://www.education.gouv.fr/cid21384/les-nouveaux-programmes-l-education-a-ladefense-renforcee.html\#troisieme > [access on July 11 ${ }^{\text {th }}$, 2013]; ID., "Concours externe du CAPES et CAFEP - CAPES Section histoire et géographie Programme de la session 2014», URL: <http://cache.media.education.gouv.fr/file/capes_externe/38/8/p2014_capes_ext_hist_geo_ 259388.pdf $>$ [access on August $19^{\text {th }}, 2013$ ].

${ }_{35}$ General Course prepares students for the general baccalaureát and to further proceed in their higher education, divided into three different structures: literary, social and economical, scientific. The Technological and Professional Course prepares those who will pursue a career in engineering, for example. 
As to the academic contribution to the programs, the traces of the second Annales generation are evident, as well as those of the current historiography tendencies, such as new political history, late modern history and contemporary history. The references to classic authors in $\mathrm{CH}$ and immediate history are present in the list of themes/problems/sentences, in the selection and emphasis on certain concepts and in the indication of supporting bibliography.

At last, for the representations of other characters, the idea of an ideological and economical obstacle attributed to Brazil (in relation to the USA, in Latin America) is flagrant. The USA is deemed as a declining power. Its interventionist action is criticized, especially when justified as an action in defense of democracy. USA's great opponent (while being a superpower), China, is dealt with from its centenary history, something unusual in the Brazilian programs. Moreover, China serves as argument to highlight the idea of multipolarity in international relations and Europe's incapacity of constituting itself as world power in the turning of the $2 \mathrm{O}^{\text {th }}$ to the $21^{\text {st }}$ century.

\section{CH in USAHigh Schools (2007-2014)}

The formulation of programs in the USA is not centralized, in spite of initiatives towards standardization, like in the famous documents produced by the Bradley Commission (BC) in $1987^{36}$, the National Council for History Standards (NCHS) in 1994-1996 and the most recent one, the Common Core State Standards (CCSS), under implementation in 45 States since 201037. This decentralization extends itself from the Statesto the city, the district and all the way through to the schools. It also advances on the ways in which History is prescribed for high school education. It is aSocialStudies content and there are many ways in which this area is organized ${ }^{8}$.

$\mathrm{CH}$ predominates in the national documents (BC and NCHS - CCSS does not bring substantive contents). Both of them (BC and NCHS) maintain a common history core constructed since the beginning of the $20^{\text {th }}$ century - Civil War, Progressivism, Great

${ }^{36}$ BRADLEY COMMISSION ON HISTORY IN SCHOOLS, Building a History Curriculum: Guidelines for Teaching History in Schools, Washington D.C., Educational Excellence Network, 1988.

${ }^{37}$ Common Core State Standards for English Language Arts \& Literacy in History/Social Studies, Science, and Technical Subjects, 2009, URL: < http://www.corestandards.org/ELALiteracy/ > [access on December $\left.30^{\text {th }}, 2014\right]$.

${ }^{38}$ NCHS 1993, 1997, 2004: NATIONAL COUNCIL FOR THE SOCIAL STUDIES, «"Principles of teaching and learning". Expectations for excellence: Curriculum Standards for Social Studies», in Social Education, 57, 5/1993, pp. 213-226; ID., Program Standards for the Initial Preparation of Social Studies Teachers (Revised 2004), vol. 2, Silver Spring [Maryland], NCSS, 2004 [prepared initially in 1997]; ID., National Standards for Social Studies Teachers (Revised 2002), vol. 1, Silver Spring [Maryland], NCSS, 2006 [prepared initially in 1997]. 
Depression, democracy movements ${ }^{39}$-, but also incorporate privileged themes in USA contemporary history: Cold War, Vietnam War, Welfare State ${ }^{40}$.

In the matter of the nature of the present time, we notice that, between $\mathrm{BC}$ and NSH (National Standards for History, produced by NCHS), the elements belonging to the semantic field of present time persist: "present”, "contemporary", "recent times", "our own present time", "current events" or "very recent events". But the importance of its study is enlarged in quantity and quality. While in the BC document only one arrangement in content organization - California's History-Social Science Framework (amongst the four suggested by the Commission) - destines one grade $\left(12^{\text {th }}\right)$ for the teaching of $21^{\text {st }}$ century history and geography, the programs for high school projected by the NSH give the $20^{\text {th }}$ century $29 \%$ space in the number of learning expectations inside the program of History of the USA and 35\% in World History.

Moreover, BC brings no comments on the importance of the present time as an object of knowledge. On the other hand, the NSH's formulators discuss the problems of studying it, revealing the survival of the «noble dream» of history objectivity, cultivated since the end of the $19^{\text {th }}$ century by the North American historiography ${ }^{41}$. In these considerations, the present time is a period with an oscillating initial point between 1968 (the failure of the neoliberal economical policy, for example) for the North American history and 1941 (the entry into World War II) for the world history. The present is also a "past that will not pass" in USA history, whether positively (Crash and World War II memories) or negatively (Vietnam War memories).

Being a painful period and memory, the present narrated by the historians is predominantly praised as guidance to the students' actions in their own lives. It teaches lessons and allows decision making,which should maintain, in the near future, the elements in the North American experience which are valued in the NSH: USA's distinguished role in the world and the principles that identify the country, such as those concerning the battle for democracy. Hence, the NSH curiously display an attitude criticized and abolished by the historians in the American Historical Association (AHA) in the 1940's decade - teaching History as an example for life. These professionals were actually against the studying of the present as an object in school ${ }^{42}$.

\footnotetext{
${ }^{39}$ MOURA, Gerson, História de uma história, São Paulo, EDUSP, 1995.

40 ALEXANDER, Gerard, Contemporary Conservatism and Contemporary History in the United States, in BRIVATI, Brian, BUXTON, Julia, SELDON, Anthony, The Contemporary History Handbook, Manchester, Manchester UniversityPress, 1996, pp. 185-197.

${ }^{41}$ NOVICK, Peter, That Noble Dream: The 'Objectivity Question' and the American Historical Profession, Cambridge: Cambridge University. Press, 1988.

${ }^{42}$ WESLEY, Edgar B., American History in Schools and Colleges. The Report of the Committee on American History in Schools and Colleges of The American Historical Association, The
} 
In the State curricula standards (who donot have any legal obligation to incorporate the substantive contents suggestions present in the national documents), the $20^{\text {th }}$ century experience is dominant in $70 \%$ of the programs in the 50 States, varying between $100 \%$ and a third of the whole space of each program.

On the nature of this present, we recognize a common core in national terms just as much as in international ones. As to this last one, we notice that it matches the history of historiography of the $20^{\text {th }}$ century, produced especially between the $1980 \mathrm{os}$ and 1990s. World War II, World War I, Cold War and Independence Movements are the most frequent events, being present in $50 \%$ or more of the State programs. The approach and the suggestions to interpret them vary in ideology and levels of commitment. It is even possible to establish a progression: (1) the further back in time - World War I - the higher the consensus; (2) the closer to the North American experience - Cold War - and less threatening (Independence Movements) - the less committed expectations are. Finally, (3) the more generic the experience is - World War II - the wider is the range of divergent interpretations offered to the students.

The $2 \mathrm{O}^{\text {th }}$ century experience is more diffuse in the North American national history, sharing the same past events with the transnational experience, besides the Great Depression and the Civil Rights Movement.The presence of the academic core contents is more visible inside the national history ones: gender, African-American, civil rights, progressivism, New Deal, anticommunism are widely mentioned and presented as contents pertaining the students' formation. However, the way in which events (in part or as a whole) are treated evidently differ, given the understandable emphasis on the outcomes of World War I and II and Cold War in internal affairs policies, which molded behaviors, altered the distribution of wealth and changed the notion of civil freedom. But they also differ in the authors' fragile commitment to the formulation of expectations. High complexity abilities - "explain”, “criticize interpretations", "formulate hypothesis", "take a stand", etc. - and the requiring of "causes" and "consequences" are seldom accompanied by the corresponding induction, that is, by the positioning or choices of positioning from the standards authors. Thus, we may conclude that the expectations of the common core contents in transnational experience are more critical than those belonging to the national ones.

Mississippi Valley Historical Association, The National Council for the Social Studies, New York, The Macmillan Company, 1944. 


\section{Comparing Experiences}

Throughout the analyses, we have attested that the school subject of History in these three countries is claimed as a component to build citizenship, in spite of the significant differences between the Brazilian, North American and French propositions.

But thishasbeenalready anticipated. What we did not expect was that the effectiveness of some $19^{\text {th }}$ century ideals would be hard to accomplish in the documents themselves. The principles of the 1988 Constitution in Brazil were mutilated in the curricula documents at the moment of their appropriation. Values donot seem to belong to the historians' agenda. They are frequently and inaccurately mistaken with the stereotyped "civics and moral education" lessons and it is not rare to find citizenship based on a triad identity (whites + blacks + natives).

In France, there is a flagrant contradiction between the alleged equal conditions assumed by the adoption of a national History curriculum and the freedom of interpretation (on behalf of the textbook authors) and teaching practices (on the teachers' side).

In the USA, we see many different types of interpretation for the role of citizenship in History teaching - since the classical "well informed and conscious participation in public life" to the defense of the "free market".

By comparing the three cultures, we also realize that indiscriminate designations are given to $\mathrm{CH}$. Although not extensively justified, the ideal type of $\mathrm{CH}$ (configured along the $20^{\text {th }}$ and $21^{\text {st }}$ centuries' experience) is very similar in duration and eventfulness. Commonplace contents dominate these three countries standards, constituted by answers to the $19^{\text {th }}$ century imperialism, World War I, 1929 Crash, World War II, Cold War, decolonization, USSR collapseand globalization. What varies is the amount ofinteractions between the national, the world, continental and global levels as well as the values conveyed through each one of them.

Without managing to get rid of metaphors, we feel compelled to conclude that the North American present is self-centered, the French one is nostalgic and the Brazilian resentful. The same commonplaces are employed to transmit a message to the citizensto-be. $70 \%$ of the 50 States in the USA consider present events more important. $49 \%$ of the learning expectations in these States are destined to the examination of the $20^{\text {th }}$ and $21^{\text {st }}$ centuries, with large room for the nation's experience (59\%). They keep USA's and world's history apart, even though a great deal of the events belonging to the world 
history are taken from the national experience as well. Nevertheless, this condition doesnot seem to bother the curricula formulators.

In France and Brazil there are only "histories". The present time occupies a total of $25 \%$ of the expectations assigned for high schools in Brazil. The concern reaches the paradox of minimizing the European experience, but at the same time maintaining it as the cause of our social problems. Transnational experience, however, builds up to $42 \%$ total of the experience, while the national experience occupies $28 \%$. The focus on Africa, which could serve as an alternative to the commonly criticized Eurocentrism, is turned to the period before the $15^{\text {th }}$ century. What present could Paleolithic Africa hold for us?

In France, the challenge is to preserve a national memory and a broader citizenship that also comprises the ex-colonies memories inside the hexagon. There are different History programs for the Lycées, depending on the distinct formation courses, but they all study Pre-History, Ancient, Middle, Modern, Contemporary and Present History. But the present time occupies $68 \%$ of the total of expectations. Proportionally, it is mainly national (46\%), in face of the world (32\%) and European (22\%) experiences. Whoever affirms that us Brazilians are much more Francophile than the French themselves in terms of chronological objects (Ancient, Middle, Modern and Contemporary) in the final years of mandatory education is right.

There is an evident contribution of Contemporary, Immediate and Late Modern historians in the land of Marianne. Even though schoolteachers and State inspectors have great responsibility over the elaboration of programs, the high level of instruction and the historians' high level of involvement in national politics seem to contribute much more than in Brazil to the direct transference from academic research to learning expectations.We almost do not mention the present time or $\mathrm{CH}$ as a dimension of historiographic reflection or as a mean to discuss recent memory in the State documents in Brazil. We believe that is not very harmful since these programs have little power of intervention inside the school. In Brazil it is textbook that serves as guide to the inexperienced teacher or to the resigned one. We may not have debated it in this article, but we dare say it is through these textbooks that $\mathrm{CH}$ discussions reach the teachers' ears.

In the USA, a surprise at last. Present time is a matter for discussion since the 1940s. The educators' pragmatism and the social and economical presentism of the last century's first three decadesmay have been the great responsible for the introduction of current events into Social Studies, and consequently into the teaching of History. Actually, contemporaneity has invaded the North American historiography since the 
1960s. But the historicization of present as an object in History teaching seems to be a more recent phenomenon, since current events and history were two different things in the beginning of the $20^{\text {th }}$ century, possibly separated by the line of methodic objectivity. Commonplace vocabulary derived from the methodic school predominates on the designated uses of this present, except for Brazil, who seems to overlook the syntax ineducational objectives. The historians' abilities are largely required to compose the learning expectations, along with substantive contents and predispositions. It is explicit in France's case. Programs use and abuse of research procedures without ever alluding to the centenary introduction of History into Sorbonne via scientific normative. In the USA, this normative is combined with abilities coming from social sciences. Together, abilities and historical knowledge are distributed under different logics of progression, spread along levels, grades, years and cycles, putting into practice old principles that respect students' different capabilities. The exception here is Brazil once more. The idea of progress is rarely taken into account by the programs' authors. 


\section{* The author}

Itamar Freitas is Professor in History Department of University of Brasília (UnB).

URL: < http://www.studistorici.com/progett/autori/\#Freitas >

\section{Per citare questo articolo:}

FREITAS, Itamar, «Contemporary History in High Schools : Brazilian, North American and French Content Standards (1999-2014)», Diacronie. Studi di Storia Contemporanea : "Se creare è definire", 29/03/2016,

URL:< http://www.studistorici.com/2016/03/29/freitas_numero_25/ >

\section{Diacronie Studi di Storia Contemporanea $\beta$ www.diacronie.it}

Risorsa digitale indipendente a carattere storiografico. Uscita trimestrale. redazione.diacronie@hotmail.it

Comitato di redazione: Jacopo Bassi - Luca Bufarale - Elisa Grandi - Antonio César Moreno Cantano - Deborah Paci - Fausto Pietrancosta - Alessandro Salvador - Matteo Tomasoni - Luca Zuccolo

Diritti: gli articoli di Diacronie. Studi di Storia Contemporanea sono pubblicati sotto licenza Creative Commons 3.0. Possono essere riprodotti e modificati a patto di indicare eventuali modifiche dei contenuti, di riconoscere la paternità dell'opera e di condividerla allo stesso modo. La citazione di estratti è comunque sempre autorizzata, nei limiti previsti dalla legge. 